\title{
Characterization of an Endemic Plant Origanum grosii from Morocco: Trace Element Concentration and Antihyperglycemic Activities
}

\author{
H. El hassouni, ${ }^{1}$ M. Bouhrim, ${ }^{2}$ R. El hajji, ${ }^{3,4}$ M. Bnouham $\mathbb{D D}^{2}{ }^{2}$ A.Ziyyat $\mathbb{D}^{2},{ }^{2}$ and A. Romane $\mathbb{D}^{1}$ \\ ${ }^{1}$ Laboratory of Applied Chemistry and Biomass, Faculty of Sciences Semlalia, Cadi Ayyad University, BP. 2390, Marrakech, \\ Morocco \\ ${ }^{2}$ Laboratoire de Bio-Ressources, Biotechnologies, Ethnopharmacologie et Santé-Faculty of Sciences, University Mohamed Premier, \\ Oujda, Morocco \\ ${ }^{3}$ Laboratory of Applied Organic Chemistry, Faculty of Science and Techniques, BP. 2202, Fès, Morocco \\ ${ }^{4}$ REMINEX Research Center, Managem Group, Marrakech, Morocco
}

Correspondence should be addressed to A. Romane; romane@uca.ac.ma

Received 11 September 2020; Revised 31 March 2021; Accepted 17 April 2021; Published 26 April 2021

Academic Editor: Murat Senturk

Copyright (C) $2021 \mathrm{H}$. El hassouni et al. This is an open access article distributed under the Creative Commons Attribution License, which permits unrestricted use, distribution, and reproduction in any medium, provided the original work is properly cited.

Origanum genus is one of the most widely used herbs in folk medicine for its biological properties. The present investigation aims to characterize, for the first time, endemic Origanum grosii collected from the Taounate region, Morocco. This characterization was realized by determining the concentration of metals in different parts of the plant (flowers, leaves, and stems) by ICP-MS, and the results were studied statistically by Principal Component Analysis (PCA). Phytochemical screening with the dosage of polyphenols and flavonoids has been conducted. To know more about this species, antihyperglycemic tests have been performed to highlight the presence or absence of the antidiabetic effect for this plant. An Oral Glucose Tolerance Test (OGTT) has been performed on normal mice which were divided into two groups of six mice each. Group 1 (control group) was treated with distilled water, and group 2 was treated with an aqueous extract of $O$. grosii by gavage at $150 \mathrm{mg} / \mathrm{kg}$. Digestive enzyme $\alpha$-amylase inhibition assay has also been evaluated to study the inhibition effect of the studied extract using acarbose as a control. The results showed that the leaves exhibited a high concentration of trace elements $(\mathrm{Ca}, \mathrm{Mg}$, and $\mathrm{K}$ ) and total absence of heavy metals, which were found in small quantities $(\mathrm{Cr}, \mathrm{Ni}$, and $\mathrm{B})$ on the stems, and this makes the plant safe to use. On the other hand, tannins, flavonoids, triterpenes, and steroids were the major families strongly present in this species. The antidiabetic results showed that O. grosii have significantly reduced postprandial hyperglycemia after glucose loading in normal rats. It showed also that this species has a significant antihyperglycemic activity reflected by the inhibition of $\alpha$-amylase. The one responsible for this property could be the synergy between the trace elements and the nature of the chemical families of O. grosii species, which can make this plant useful in the management of postprandial hyperglycemia.

\section{Introduction}

Medicinal plants have been used in folk medicine against a lot of diseases for thousands of years [1-3]. It has been confirmed by the World Health Organization (WHO) that approximately $80 \%$ of people traditionally use medicinal and aromatic herbs for the treatment of many diseases [4].

The herbals unfortunately also have side effects, such as nature and concentration of the mineral components. Some metals as $\mathrm{As}, \mathrm{Cd}, \mathrm{Hg}, \mathrm{Pb}$, or Se are not essential for plant growth. Others such as $\mathrm{Co}, \mathrm{Cu}, \mathrm{Fe}, \mathrm{Mn}, \mathrm{Mo}, \mathrm{Ni}$, and $\mathrm{Zn}$ are essential elements required for normal growth and metabolism of plants, but when their concentration is greater than optimal values, these elements can easily lead to poisoning [5-9]. On the other hand, there are the wild dumps that constitute chemical contamination, especially of heavy metals, and accumulates in the soil and under certain biogeochemical conditions can pass into the soil solution 
$[10,11]$ and, therefore, become bioavailable and absorbed by plants [12].

In this sense, scientific researchers have been obliged to fix norms in terms of plant mineral composition; for example, the WHO declared that the presence of heavy metals should be checked for some medicinal plants used as ingredients in herbal formulations (teas, tinctures, etc.) [13]. Therefore, we should check the heavy metal concentrations in medicinal plants and their products to ensure the safety and efficacy of herbal products $[2,14]$.

On the other hand, the advantages of medicinal plants are enormous, especially in the pharmacological sector by discovering new components coming from natural sources to fight against several diseases [15-18]. Besides, to determine the chemical profile and composition of medicinal plants, several studies show the complexity and variety of compounds that all contribute to the various uses of plants in the processing of many foods, including life-threatening diseases such as AIDS, cancer, and diabetes [2, 19].

Diabetes is one of the oldest diseases whose devastating effect is increasing day by day and severely at an epidemic level [20]. Generally, there are two types of diabetes: type 1 diabetes is an autoimmune disease in which the $\beta$ cells of the pancreas do not produce sufficient insulin (a hormone that helps use blood sugar (glucose) for energy). Type 2 diabetes is the interaction between several genetic and environmental factors that results in a heterogeneous and progressive disorder with variable degrees of insulin resistance and pancreatic $\beta$-cell dysfunction. When $\beta$ cells are not longer able to secrete sufficient insulin to overcome insulin resistance, impaired glucose tolerance progresses to type 2 diabetes [21].

This disease is the most frequent in the world affecting $7 \%$ of the population or 285 million people worldwide. It is predicted that this number will exceed 435 million in 2030 [22].

Despite the use of hypoglycemic as antidiabetic drugs, diabetes and its complications constitute a major problem in the therapeutic management of diabetics and the success of treatment would be more interesting. Despite the progress of new therapeutic molecules, modern drugs, including insulin and oral hypoglycemic agents, have shown an unwanted effect when administered regularly $[23,24]$. Recently, diabetologists conclude that a therapeutic complement consisting of plant extracts is necessary to optimize the treatment of diabetes $[25,26]$ due to their perceived effectiveness, safety, affordability, and acceptability, with minimal side effects in clinical experience and relatively low cost $[27,28]$. The World Health Organization recommends the use of traditional and plant-based medicines for the management of diabetes mellitus [29].

The Origanum genus is among the plants whose antidiabetic properties are well known $[30,31]$. This genus is presented in five species in Morocco; three of them are endemic, O. compactum, O. elongatum, and O. grosii, which are our interest in this paper [32]. To the best of our knowledge, no pharmacological work was carried out on the species O. grosii to characterize and evaluate this species. This work has two objectives: firstly, determining, by ICP-
MS, its mineral proportions, trace elements, and heavy metals to ensure the safe and efficient use of the plant in therapeutic medicine. After determining the chemical families of the studied plant via photochemical screening and the dosage of polyphenols and flavonoids, our second objective will aim to evaluate the plant by studying its antihyperglycemic activities by two tests: an Oral Glucose Tolerance Test (OGTT), in normal mice, and $\alpha$-amylase inhibition assay.

\section{Materials and Methods}

2.1. Plant Materiel. The aerial part of O. grosii was harvested during the flowering period when it produces normally maximal biomass. It was collected in July 2015 from the Taounate region (Taher souk), Morocco. The species was identified in the scientific institute of Rabat in Morocco; the Voucher specimens (99125) were deposited in its herbarium.

\subsection{The Analysis of Metals by ICP-MS Methods}

2.2.1. Devices and Reagents. In this study, a Thermo Fisher $\mathrm{X}$ Series II (Thermo Fisher Scientific, Bremen, Germany) with an autosampler ASX-510 (Cetac, Omaha, Nebraska, USA) was used in standard configuration. The instrument was equipped with a standard monobloc torch with a quartz injector tube (internal diameter: $1.5 \mathrm{~mm}$ ).

The introduction system is composed of a Micromist microcentric nebulizer (Glass Expansion, USA) associated with a so-called Scott double passage nebulization chamber cooled to $2^{\circ} \mathrm{C}$ by the Peltier effect.

The instrument was optimized (daily performance) to give maximum sensitivity to $\mathrm{M}^{+}$ions and double ionization and oxides, controlled by rations between $\mathrm{Ba}_{2}^{+} / \mathrm{Ba}^{+}$and $\mathrm{Ce}_{2}{ }^{+} / \mathrm{CeO}^{+}$respectively, these being always less than $2 \%$. The experimental conditions were argon debit on a nebulizer $\left(0.8 \mathrm{~L} \cdot \mathrm{min}^{-1}\right)$, auxiliary gas debit $0.84 \mathrm{~L} \cdot \mathrm{min}^{-1}$, argon debit in plasma $4.5 \mathrm{~L} \cdot \mathrm{min}^{-1}$, lens voltage $7.30 \mathrm{~V}$, power RF in plasma $1100 \mathrm{~W}$, and the sampling depth (cone-torch distance) of $9 \mathrm{~mm}$.

All reagents are of analytical quality. For the preparation of the solutions and the cleaning of the materials, we used ultrapure water with a conductivity $<1 \mu \mathrm{s} \cdot \mathrm{cm}^{-1}$ obtained by purifying the demineralized water with Milli-QTM PLUS and nitric acid (67\% v/v) purified.

2.2.2. Sample Digestion Procedure. Acid digestion on a hot plate was performed following the protocol of Schwartz $[33,34]$; each sample was digested in a mixture of nitric acid, sulfuric acid, and oxygenated water. The samples are then heated slowly to $95^{\circ} \mathrm{C}$ following a temperature ramp of $2^{\circ} \mathrm{C} \cdot \mathrm{min}^{-1}$ using a digestion block (SCP Science, Montreal, QC) to avoid too strong reactions. The temperature of $95^{\circ} \mathrm{C}$ was maintained for $40 \mathrm{~min}$ until the appearance of the samples became constant. The residues were washed with nitric acid at 50\% v/v. The supernatants were filtered using Whatman filter paper to minimize the number of microparticles during the analysis that could block the liquid 
sample intake or interfere with the nebulization of the solution by the plasma used for the ICP-MS methods. The solutions are filtered and eviolated in a plastic flask. Internal standards are added to the samples at a concentration of $5 \mu \mathrm{g} \cdot \mathrm{L}^{-1}$.

2.3. Statistical Study: PCA. To treat the results of metals analysis, we used statistical studies by the software R for chemometric analysis. The loading plot tool in PCA was used to show the relationship between variables (metals) and how significant each variable was for each principal component. Also, the plot of variables (correlation plot) was used to study the dimensions and their correlation with metals. Also, the plot of individuals was used to identify groups of individuals (three parts of the plant) with similarity $[9,35,36]$.

\subsection{Characterization of Chemical Families}

2.4.1. Phytochemical Screening. The objective of phytochemical screening tests is to determine the presence or absence of some chemical families in the studied plants such as alkaloids, tannins, flavonoids, anthocyanins, leucoanthocyanines, coumarins, quinones, terpenoids, steroids, triterpenoids, carotenoids, and saponins [37, 38].

2.4.2. Polyphenol and Flavonoid Dosage. To determine the total content of polyphenols, we used the Folin-Ciocalteu method. $100 \mu \mathrm{L}$ of the diluted extract was mixed with $2.5 \mathrm{~mL}$ of Folin-Ciocalteu reagent and $2.5 \mathrm{~mL}$ of $\mathrm{Na}_{2} \mathrm{CO}_{3}$ solution. The mixture was incubated in darkness for $1 \mathrm{~h}$, and then, the absorbance was measured at $515 \mathrm{~nm}$. As a standard, we used gallic acid. The results were expressed as mg of gallic acid equivalent per gram of dry weight (mg GAE/g DW) $[39,40]$.

Concerning the flavonoid content, we used the colorimetric method of aluminum trichloride. We mixed $100 \mu \mathrm{L}$ of extract with $0.4 \mathrm{~mL}$ of distilled water, $0.003 \mathrm{~mL}$ of $\mathrm{NaNO}_{2}$ solution (5\%), and $0.02 \mathrm{~mL}$ of $\mathrm{AlCl}_{3}$ solution (10\%); after $5 \mathrm{~min}$, we added to the mixture $0.2 \mathrm{~mL}$ of $\mathrm{Na}_{2} \mathrm{CO}_{3}$ solution $(1 \mathrm{M})$ and $0.25 \mathrm{~mL}$ of distilled water. The absorbance was measured at $510 \mathrm{~nm}$, and quercetin was used as standard. The results were expressed as $\mathrm{mg}$ of quercetin equivalent per gram of extract weight (mg QE/g DW) [41].

\subsection{Antidiabetic Activities}

2.5.1. Oral Glucose Tolerance Test (OGTT), in Normal Mice. The antihyperglycemic effect of aqueous extract was evaluated as described by several others [27, 42, 43]. Normal mice (180-250 g) fasted for $14 \mathrm{~h}$ before experimentation but were allowed free access to water. The animals were divided into two groups of six mice each. Group 1 (control group) was treated with distilled water $(10 \mathrm{~mL} / \mathrm{kg})$. Group 2 was treated with an aqueous extract of $O$. grosii by gavage at $150 \mathrm{mg} / \mathrm{kg}$. All animals were orally loaded with glucose $(2 \mathrm{~g} /$ $\mathrm{kg}$ of body weight) 30 minutes after treatment. Afterward, the blood glucose variation was monitored for 2 hours.
2.5.2. Inhibitory Effect of the Plant of Pancreatic AlphaAmylase Enzyme Activity. The $\alpha$-amylase inhibition assay was conducted according to some reporters $[44,45]$, with some modifications. Briefly, $200 \mu \mathrm{L}$ of the sample (dissolved in phosphate buffer solution, the concentrations have been prepared from 3.33 to $1.66 \mathrm{mg} / \mathrm{ml}$ ) was mixed with $200 \mu \mathrm{L}$ of $\alpha$-amylase $(13 \mathrm{IU} / \mathrm{ml}$, in $0.02 \mathrm{M}$ phosphate buffer solution (PBS), pH 6.9). After incubating at $37^{\circ} \mathrm{C}$ for $10 \mathrm{~min}, 200 \mu \mathrm{L}$ of $1 \%(\mathrm{w} / \mathrm{v}$ ) soluble starch (in $0.02 \mathrm{M} \mathrm{PBS}, \mathrm{pH} 6.9$ ) was added and the mixture was further incubated at $37^{\circ} \mathrm{C}$ for $15 \mathrm{~min}$, followed by adding $250 \mu \mathrm{L}$ of dinitrosalicylic acid color reagent (DNS $1 \mathrm{~g}$ in $40 \mathrm{~mL}$ of distilled water, $30 \mathrm{~g} \mathrm{Na}-\mathrm{K}$ tartrate, $2 \mathrm{~N} \mathrm{NaOH}$ ), and stopped by heating in a boiling water bath for $8 \mathrm{~min}$. After cooling to room temperature, the mixture has been diluted with $1 \mathrm{~mL}$ of PBS and the absorbance was measured at $540 \mathrm{~nm}$.

The inhibition percentage (\%) was calculated by the following equation:

$$
\operatorname{Inhibition}(\%)=\frac{\left(A_{\mathrm{c}}-A_{\mathrm{cb}}\right)-\left(A_{\mathrm{s}}-A_{\mathrm{sb}}\right)}{A_{\mathrm{c}}-A_{\mathrm{cb}}} * 100 .
$$

Absorbances are abbreviated as follows: $A_{\mathrm{c}}$ (control), $A_{\mathrm{cb}}$ (control blank), $A_{\mathrm{s}}$ (sample), and $A_{\mathrm{sb}}$ (sample blank).

\section{Results and Discussion}

3.1. The Mineral Composition Analyzed by ICP-MS. All results are summarized in Table 1 . The results showed that $\mathrm{Ca}$, $\mathrm{K}$, and $\mathrm{Mg}$ present higher mineral values in the species.

To understand and treat these results, we used the statistical study (PCA).

3.2. Principal Component Analysis (PCA). Table 2 shows that only the first two components have eigenvalues greater than 1. This implies that these two components can be considered for the explanation of the data variability.

Figure 1 reveals the existence of correlations between most metals that are positively correlated with $\mathrm{CP} 1$ such as $\mathrm{Ca}, \mathrm{Fe}, \mathrm{Zn}, \mathrm{Al}, \mathrm{Na}, \mathrm{Mn}$, and $\mathrm{Sr}$ and $\mathrm{Ba}, \mathrm{As}, \mathrm{Pb}$, and $\mathrm{Si}$ which are positively correlated with $\mathrm{CP} 2$, although, $\mathrm{Cr}, \mathrm{B}$, and, maybe, $\mathrm{Ni}$ are negatively correlated with $\mathrm{CP} 2$.

3.2.1. Study of Individuals. From Figure 2, it is very clear that there is a birth of three groups, the leaves are presented on the right of the first component as the first group and the stems are formed as the second group on the left of the first component, while the flowers which are in the third group are placed at the bottom of the second component.

For a better and clear explication of these separations, we associated the variables (metals) and individuals (three parts of the plant) into a single figure:

By superposing the score and loading plots, we have obtained the biplot (Figure 3).

According to this graph and Figure 4 which shows the distribution of metals by size, we find that the majority of metals, especially trace elements that are positively correlated to $\mathrm{CP} 1$, are concentrated at the leaves and they are 
TAвLE 1: Descriptive statistics for heavy metal content and trace elements $\left(\mathrm{mg}^{\mathrm{kg}} \mathrm{kg}^{-1}\right)$ in Origanum grosii.

\begin{tabular}{|c|c|c|c|c|c|c|}
\hline \multirow{2}{*}{ Elements } & \multicolumn{2}{|c|}{ Flowers } & \multicolumn{2}{|c|}{ Stems } & \multicolumn{2}{|c|}{ Leaves } \\
\hline & Mean $(\mathrm{mg} / \mathrm{kg})$ & S.D (mg/kg) & Mean $(\mathrm{mg} / \mathrm{kg})$ & S.D (mg/kg) & Mean $(\mathrm{mg} / \mathrm{kg})$ & S.D $(\mathrm{mg} / \mathrm{kg})$ \\
\hline $\mathrm{Al}$ & 11.39 & 1.76 & 1.49 & 0.2 & 17.77 & 2.94 \\
\hline As & 0.04 & 0.01 & 0.07 & 0.02 & 0.08 & 0.02 \\
\hline B & 0.38 & 0.04 & 0.12 & 0.05 & 0.35 & 0.08 \\
\hline $\mathrm{Ba}$ & 0.14 & 0.03 & 0.31 & 0.16 & 0.36 & 0.19 \\
\hline $\mathrm{Ca}$ & 158.19 & 8.12 & 75.79 & 12.82 & 264.89 & 19.18 \\
\hline $\mathrm{Cr}$ & 0.52 & 0.1 & 0.48 & 0.19 & 0.44 & 0.14 \\
\hline $\mathrm{Cu}$ & 0.17 & 0.01 & 0.09 & 0.03 & 0.22 & 0.07 \\
\hline $\mathrm{Fe}$ & 22.67 & 3.07 & 4.23 & 1.61 & 36.47 & 7.61 \\
\hline $\mathrm{K}$ & 177.12 & 18.8 & 107.99 & 34.58 & 232.38 & 22.49 \\
\hline $\mathrm{Mg}$ & 40.97 & 4.76 & 11.53 & 5.89 & 50.67 & 7.17 \\
\hline Mn & 0.74 & 0.11 & 0.26 & 0.1 & 0.97 & 0.42 \\
\hline $\mathrm{Na}$ & 5.6 & 0.08 & 3.36 & 0.79 & 6.93 & 0.5 \\
\hline $\mathrm{Ni}$ & 0.19 & 0.03 & 0.15 & 0.08 & 0.21 & 0.04 \\
\hline $\mathrm{P}$ & 29.99 & 1.64 & 29.75 & 3.56 & 41.86 & 2.46 \\
\hline $\mathrm{Pb}$ & 0.09 & 0.06 & 0.12 & 0.01 & 0.15 & 0.03 \\
\hline $\mathrm{Si}$ & 2.04 & 0.32 & 2.95 & 0.43 & 4.04 & 0.25 \\
\hline $\mathrm{Sr}$ & 0.68 & 0.05 & 0.32 & 0.02 & 1.28 & 0.05 \\
\hline $\mathrm{Zn}$ & 0.33 & 0.06 & 0.17 & 0.05 & 0.46 & 0.02 \\
\hline
\end{tabular}

TABLE 2: Eigenvalues of components and percentage of variability explained in the data.

\begin{tabular}{|c|c|c|c|}
\hline Component number & Eigenvalue & Percentage of variance explained (\%) & Cumulative percentage (\%) \\
\hline Dimension 1 & 9.90082 & 55.00455 & 55.00456 \\
\hline Dimension 2 & 2.62753 & 14.59743 & 69.60199 \\
\hline Dimension 3 & 0.99523 & 5.52911 & 75.13110 \\
\hline Dimension 4 & 0.86280 & 4.79334 & 79.92444 \\
\hline Dimension 5 & 0.78431 & 4.35732 & 84.28176 \\
\hline Dimension 6 & 0.55807 & 3.10040 & 87.38217 \\
\hline Dimension 7 & 0.48469 & 2.69272 & 90.07489 \\
\hline Dimension 8 & 0.40140 & 2.23002 & 92.30492 \\
\hline Dimension 9 & 0.29846 & 1.65813 & 93.96305 \\
\hline
\end{tabular}

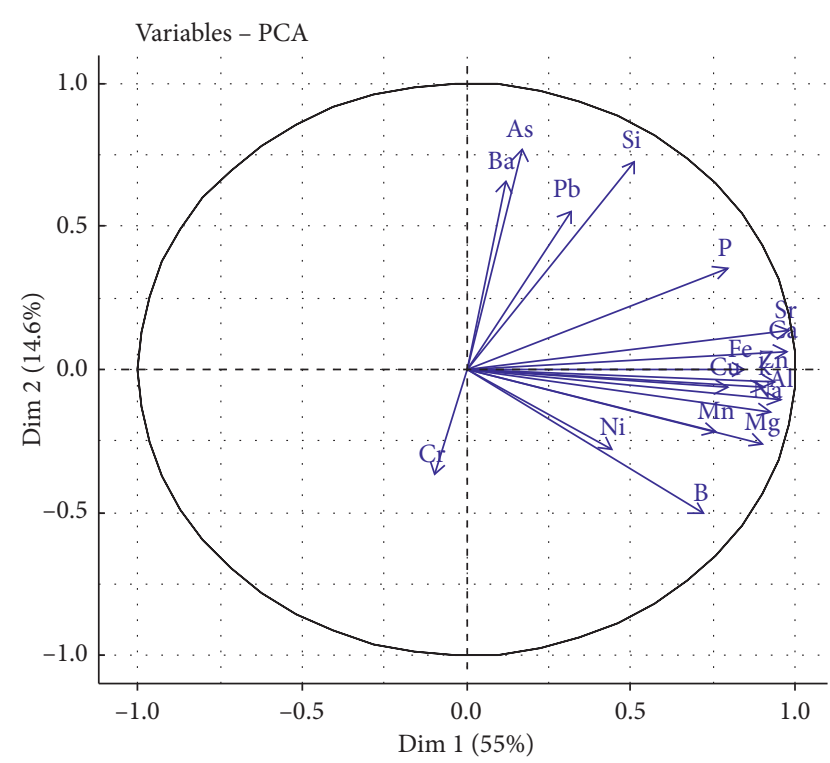

FIGURE 1: Superimposed representation of metals.

completely absent from the toxic metals. On the other hand, these heavy metals (As and Cr) were presented at the stems.
From these figures, it is clear that the leaves are the richest part in trace elements which makes them the most important part in the plant. It is also necessary to mention that the concentration of heavy metals in the stems did not exceed the optimal values declared by the WHO, which does not make this plant toxic for human.

3.3. Characterization of Chemical Families. To have a better view of the chemical families present in this plant, we carried out some phytochemical screening tests summarized in Table 3.

According to the table, tannins, flavonoids, triterpenes, and steroids are the most chemical families present in the leaves. However, tannins, triterpenes, and steroids were also present in the steams but in lesser quantities. Our results were not very different comparing with several studies conducted on other species $[46,47]$.

According to these results, we will be focused on the leaves' composition. Table 4 presents its content of polyphenols and flavonoids.

This work was compared to other studies conducted on the same genus studied by Bouyahya et al. who declared that O. compactum had less concentration of polyphenols and flavonoids compared to our results, $117.6 \mathrm{mg} \mathrm{EAG/g}$ and $27.6 \mathrm{mg} \mathrm{EQ} / \mathrm{g}$, respectively [46]. 


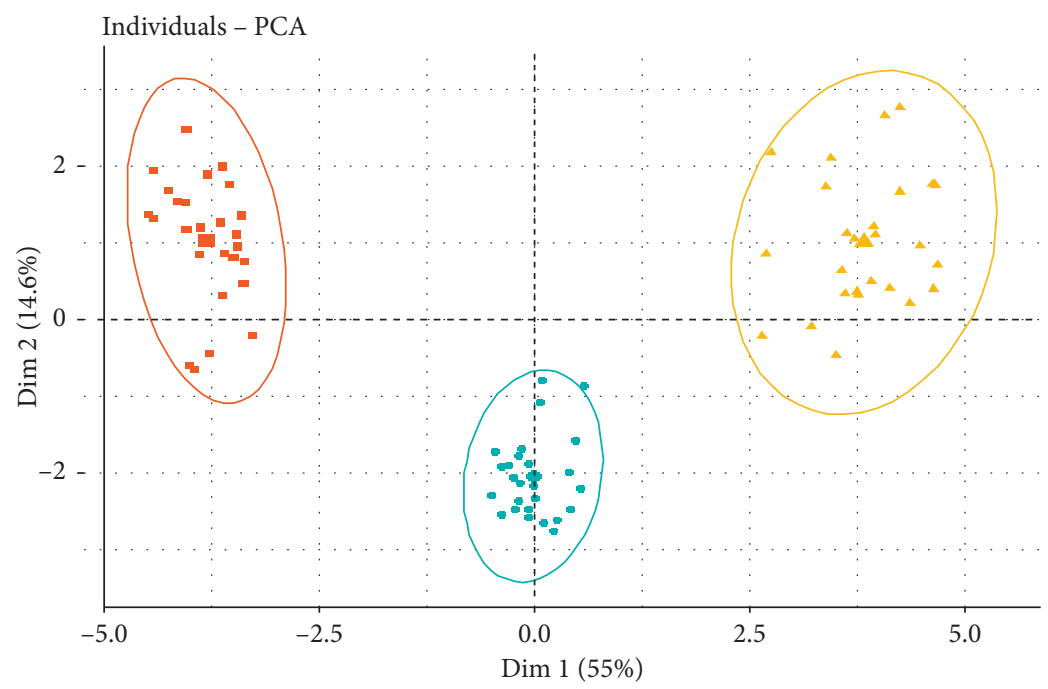

Groups
\begin{tabular}{|l|l}
\hline & $\mathrm{FL}$ \\
\hline$\square$ & $\mathrm{LV}$ \\
$\square$ & $\mathrm{ST}$
\end{tabular}

FIGURE 2: Superimposed representation of three parts of the plant.

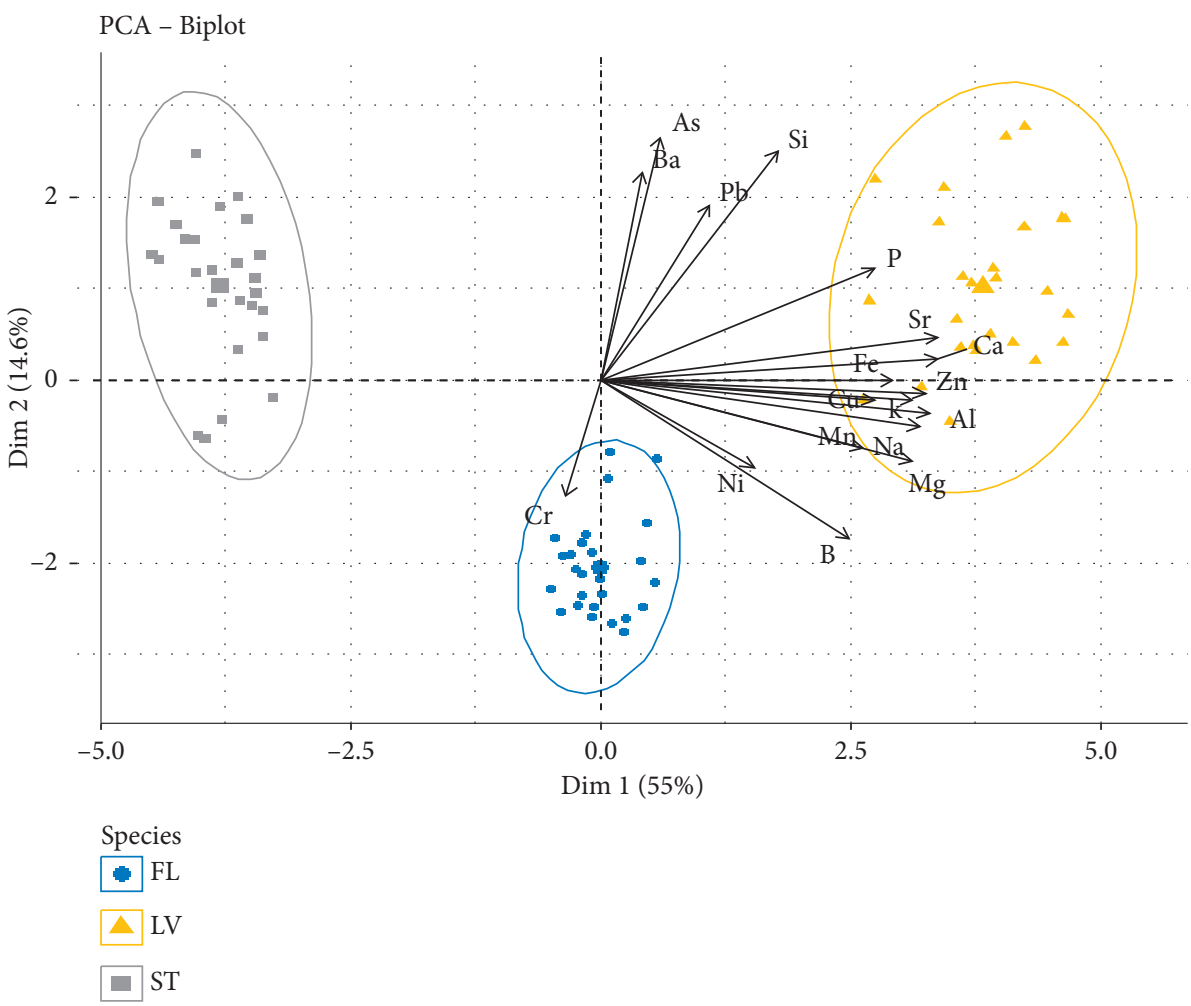

Figure 3: Superimposed representation of metals and different parts of the plant.

\subsection{Antidiabetic Activities}

3.4.1. Glucose Tolerance and Antihyperglycemic Effect. The results presented in Figure 5 showed that, in the control group, the postprandial hyperglycemia level caused by $2 \mathrm{mg} /$ $\mathrm{kg}$ of glucose at $30 \mathrm{~min}$ loading reached $180 \mathrm{mg} / \mathrm{dL}$ after glucose administration. At $90 \mathrm{~min}$, it increased to $140 \mathrm{mg} / \mathrm{dL}$ and then decreased to reach an average of $118 \mathrm{mg} / \mathrm{dL}$ at $150 \mathrm{~min}$ after loading. However, O. grosii extract at a dose of $150 \mathrm{mg} / \mathrm{kg}$ suppressed significantly the postprandial hyperglycemia level compared with the normal control group as indicated in Figure 5. The area under the curve of glucose 


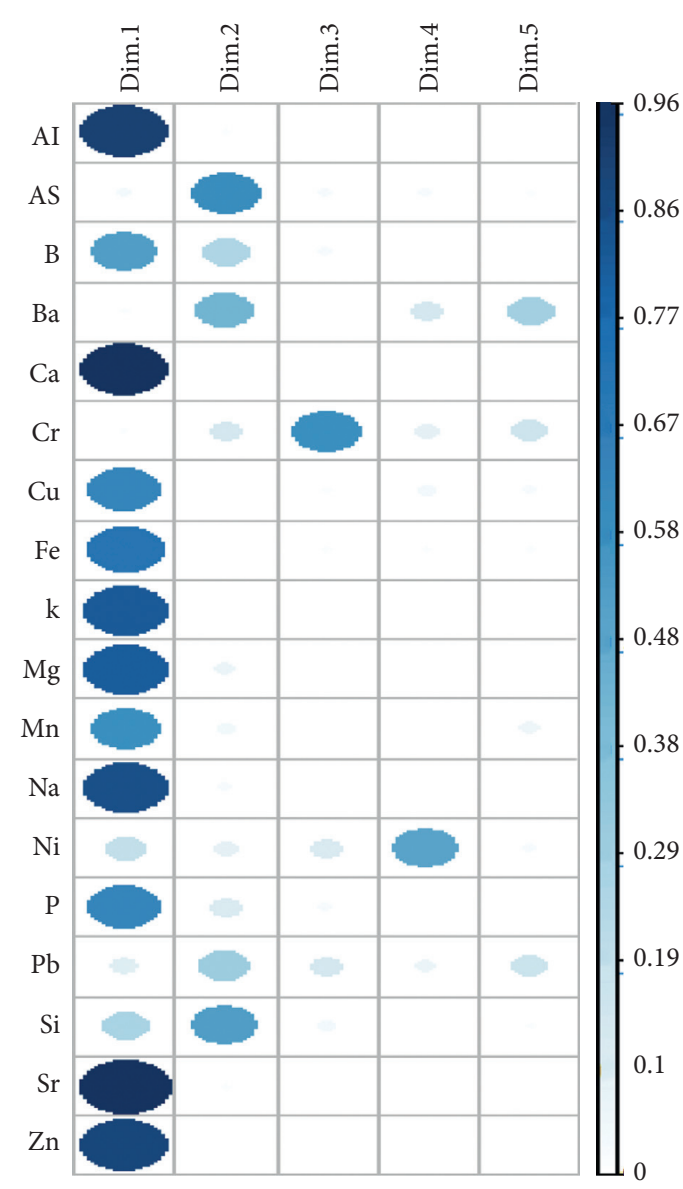

FIGURE 4: Distribution of metals by size.

TABLE 3: Phytochemical screening of leaves and stems of the species Origanum grosii.

\begin{tabular}{|c|c|c|c|c|}
\hline- & & & Leaves & Stems \\
\hline Flavonoids & & & ++ & - \\
\hline Triterpenes/stéroides & & & +++ & + \\
\hline Saponines & & & - & - \\
\hline Anthocyanes & & & - & - \\
\hline Alkaloids & & & - & - \\
\hline Caroténoïds & & & - & - \\
\hline Coumarins & & & - & - \\
\hline Quinones & & & + & - \\
\hline \multirow{2}{*}{ Tannins } & & Catechic & +++ & + \\
\hline & & Gallic & +++ & + \\
\hline \multirow{4}{*}{ Antraquinones } & \multirow{4}{*}{ Combinés } & Libres & - & - \\
\hline & & O-hétérosides & - & - \\
\hline & & O-hétérosides à génine réduite & - & - \\
\hline & & C-hétérosides & - & - \\
\hline
\end{tabular}

TABle 4: Polyphenol and flavonoid content of Origanum grosii leaves.

\begin{tabular}{lc}
\hline Polyphenols $(\mathrm{mgGAE} / \mathrm{g})$ & Flavonoids $(\mathrm{mgQE} / \mathrm{g})$ \\
\hline $136.5 \pm 1.2$ & $50.1 \pm 2.0$ \\
\hline
\end{tabular}

tolerance (AUC glucose) for the O. grosii-extract-treated group was significantly lower than that of the normal control group; this result presents an antihyperglycemic effect of this species. These results were similar compared to another study conducted on Mexican oregano for normal and diabetic fasting mice [48] and also another study conducted on another plant which was less than $125 \mathrm{mg} / \mathrm{dL}$ [49]. According to several works $[50,51]$, this may be due to the presence of a large hypoglycemic chemical family such as flavonoids, terpenes, and tannins which are present in our species (phytochemical screening results). Those components improve the performance of pancreatic tissues by 


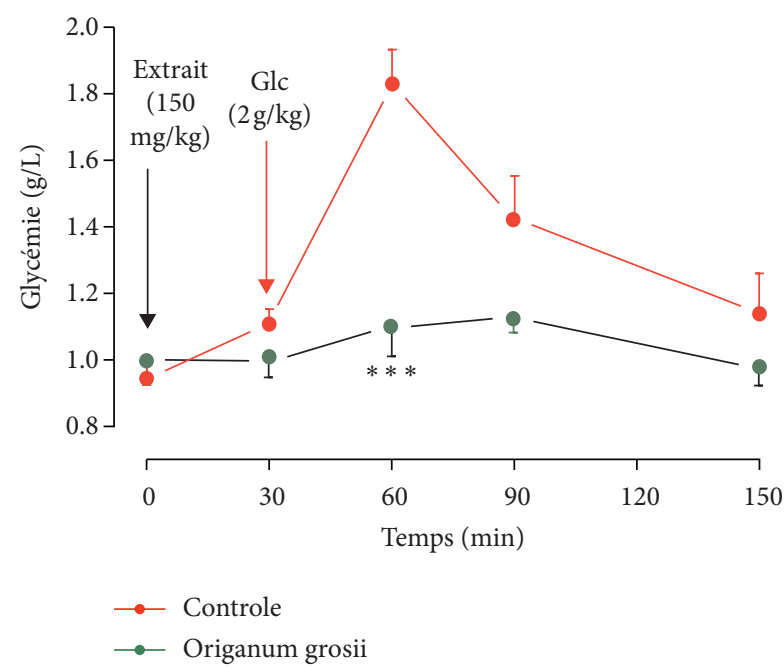

FIgURE 5: Antihyperglycemic effect of O. grosii extract in normal rats.

increasing insulin secretion or decreasing the intestinal absorption of glucose [52]. For this reason, our study needs more advanced research. Overall, for some authors, Lamiaceae is among the families of plants with the most potent hypoglycemic effects included $[53,54]$.

3.4.2. Alpha-Amylase Inhibitor Activity. Percent alphaamylase inhibition of the studied species was plotted as a function of concentration in comparison with acarbose, as shown in Figure 6. The inhibitory effect of the studied plant was inferior to that of acarbose. The results indicate that the plant extract $(3.33 \mathrm{mg} / \mathrm{ml})$ had a good exhibition antialpha-amylase activity compared to that of the lower concentration $(1.66 \mathrm{mg} / \mathrm{ml})$.

To control postprandial glycemic levels for the management of diabetes, the inhibition of digestive enzymes is a great strategy for glucose control [55], $\alpha$-amylase, which results in a significant reduction in postprandial blood glucose, presenting an important goal in diabetes management [56]. In addition, a microbial pseudotetrasaccharide, acarbose, inhibits the brush border enzymes glucoamylase, dextrinase, maltase, and sucrase, as well as pancreatic $\alpha$-amylase [55]. Despite the effectiveness of acarbose as an antidiabetic drug, alternative foods are necessary. Moreover, due to the side effects of acarbose and rare cases of hepatotoxicity which have been recorded as a result of long-term consummation [44], scientists are interested in nutritional therapies and functional foods with preventive effects on diabetes and obesity [56]. Few articles have described the inhibitory activities of the Origanum genus [30,57]. Yet, none of the previous studies have been recorded on the O. grosii species. As is known, Origanum leaves are currently used for the treatment of type 1 and type 2 diabetes mellitus $[30,31,58]$. The dose of Origanum used $(20 \mathrm{mg} / \mathrm{kg})$ is effective for 2 weeks to normalize blood glucose levels in severely diabetic rats. We can report that the antihyperglycemic effect of Origanum is very potent and

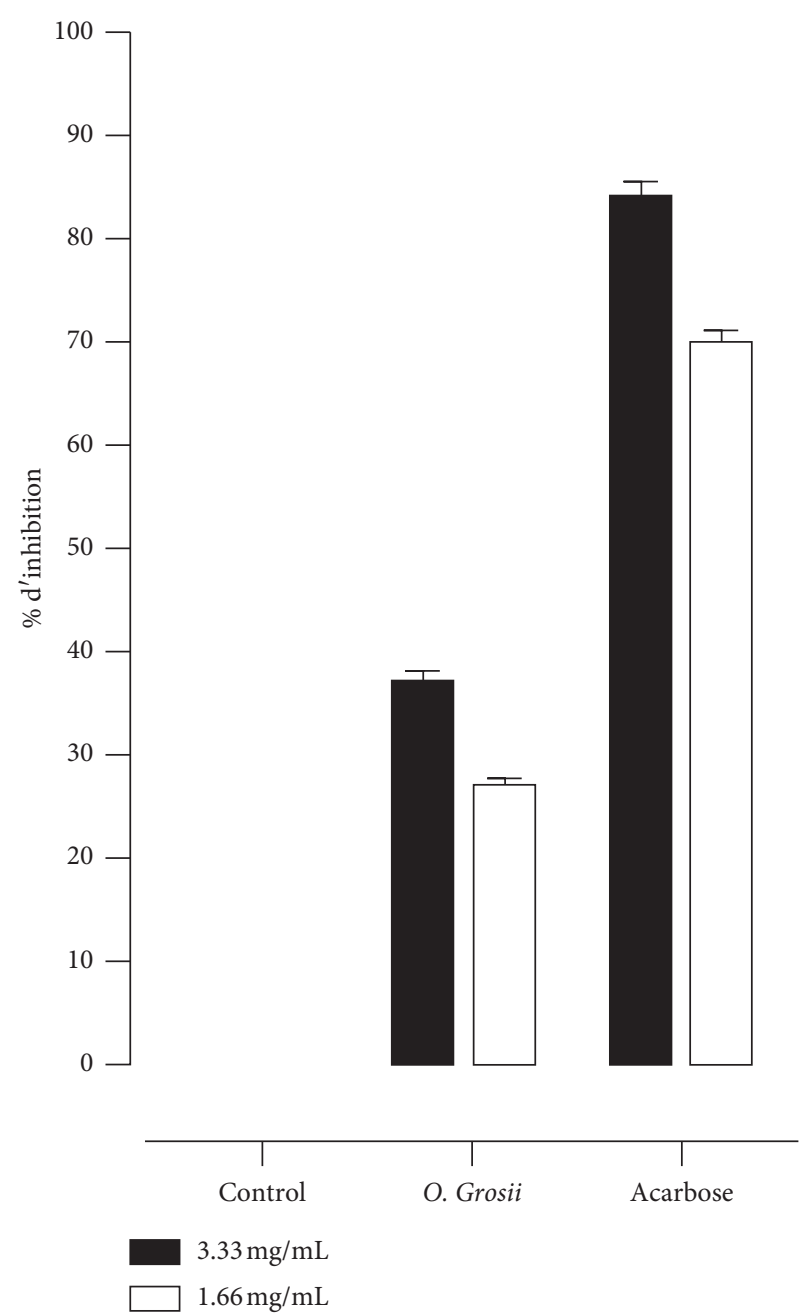

FIGURE 6: Inhibitory effect of extracts on pancreatic alpha-amylase enzyme activity.

cumulative. The plant extract also can be effective as an inhibitor of renal tubular glucose reabsorption [58, 59].

The present study indicated that Origanum grosii species could be useful in the management of postprandial hyperglycemia. The antienzymatic activity of the species is probably due to its phenolic content, which necessitates a deep study on this activity, as well as a chemical separation that will allow the extraction of compounds responsible for this property.

Minerals and trace elements are important agents for biochemical reactions. They are considered to be a stabilizer of enzymes and proteins as cofactors. Many trace elements affected the biological processes by binding the receptor site of the cell membrane or preventing the entry of particular molecules into the cell by changing the shape of the receptor [60]. Macroelements, primarily calcium $(\mathrm{Ca})$, potassium $(\mathrm{K})$, magnesium $(\mathrm{Mg})$, chloride $(\mathrm{Cl})$, phosphorous $(\mathrm{P})$, sodium $(\mathrm{Na})$, and iron $(\mathrm{Fe})$, and certain trace elements such as cobalt (Co), boron (B), chromium $(\mathrm{Cr})$, copper $(\mathrm{Cu})$, sulfur $(\mathrm{S})$, iodine $(\mathrm{I})$, zinc $(\mathrm{Zn})$, and molybdenum (Mo), enhance insulin action by activating insulin receptor sites [61-63]. 
Journal of Chemistry

Several works explained the relation between the trace elements $(\mathrm{Zn}, \mathrm{Cr}$, and $\mathrm{Mg})$ and the antidiabetic activity. They explained also the deficiency of some trace elements in diabetic patients that play a great role in the development of diabetes mellitus [64-67]. Ahmed et al. reported that several trace elements are significantly reduced in people with diabetes mellitus $[67,68]$. Also, other work reported that the trace elements $\mathrm{Ca}$ and $\mathrm{K}$ regulate voltage-dependent channels in pancreatic $\beta$-cells, which are essential for insulin exocytosis [69-71]. Ekmekcioglu et al. indicated that potassium's role in the control of blood glucose is grounded in its function at a cellular level where potassium-induced cell depolarization results in insulin secretion from pancreatic $\beta$ cells [72]. Similarly, Stone reported that the appropriate potassium intake may influence the control of glucose, limiting, therefore, the risk of diabetes, especially in those on thiazide diuretic treatment and those already at higher risk from the development of additional comorbidities [73]. Also, Helderman et al. confirm the impact of potassium on the thiazide administration used to decrease glucose [74]. Other studies have shown a complex association between calcium levels and the pathogenesis of diabetes. The decreased $\beta$-cells' function was related to abnormal calcium regulation $[63,75]$.

The research mentioned above proved the principal protective role of trace elements against diabetes mellitus. Then, the plants which have insulin-mimetic, hypoglycemic, and antidiabetic properties may conduct them by helpful effects of trace element contents.

\section{Conclusions}

In conclusion, the mineral composition of $O$. grosii did not exceed the limit values required by the WHO, which makes it safe for human use. Origanum is one of the natural herbal medicines rich in antidiabetic compounds (flavonoids, tannins, and phenolic) that improve the performance of pancreatic tissues by increasing the insulin secretion or decreasing the intestinal absorption of glucose, and the antihyperglycemic action of this plant can be partially attributed to the inhibition of $\alpha$-amylase or other enzymes. The chemical families of the Origanum plant could act separately or in synergy to cause the hypoglycemic effect of the genus. Besides, other studies are necessary to determine the chemical composition and separate the active components of plants, to identify the compounds responsible for this activity. Moreover, because of trace element variations between the studied plants, the hypoglycemic effect of these herbs is not due to a unique element present in the herbs, rather a synergic effect of several elements that might account for the hypoglycemic nature of these plants. Other works are necessary to evaluate this phenomenon. Hence, based on the found results, it is approved to say that the studied species might be used in diabetes treatments without ignoring testing its toxicity on humans.

\section{Data Availability}

No data were used in this study.

\section{Conflicts of Interest}

The authors declare that they have no conflicts of interest.

\section{References}

[1] N. H. Rakotoarivelo, F. Rakotoarivony, A. V. Ramarosandratana et al., "Medicinal plants used to treat the most frequent diseases encountered in Ambalabe rural community, Eastern Madagascar," Journal of Ethnobiology and Ethnomedicine, vol. 11, p. 68, 2015.

[2] R. A. Street and G. Prinsloo, "Commercially important medicinal plants of South Africa: a review," Journal of Chemistry, vol. 2013, Article ID 205048, 16 pages, 2013.

[3] W. Abdelli, F. Bahri, A. Romane et al., "Chemical composition and anti-inflammatory activity of Algerian thymus vulgaris essential oil," Natural Product Communications, vol. 12, no. 4, pp. 611-614, 2017.

[4] A. Shah, A. Niaz, N. Ullah et al., "Comparative study of heavy metals in soil and selected medicinal plants," Journal of Chemistry, vol. 2013, Article ID 621265, 5 pages, 2013.

[5] I. Khan, J. Ali, and H. Tullah, "Heavy metals determination in medicinal plant Withania somnifera growing in various areas of Peshawar, NWFP," Journal of the Chemical Society of Pakistan, vol. 30, pp. 69-74, 2008.

[6] J. Singh and A. S. Kalamdhad, "Effects of heavy metals on soil, plants, human health and aquatic life," International Journal of Research in Chemistry and Environment, vol. 1, pp. 15-21, 2011.

[7] M. Y. Arjouni, M. A. Bennouna, M. A. El Alaoui El Fels, and A. Romane, "Assessment of mineral elements and heavy metals in leaves of indigenous cypress of High Atlas Mountains," Natural Product Research, vol. 29, no. 8, pp. 764-767, 2015.

[8] F. A. Ababneh, "The hazard content of cadmium, lead, and other trace elements in some medicinal herbs and their water infusions," International Journal of Analytical Chemistry, vol. 2017, Article ID 6971916, 8 pages, 2017.

[9] M. Ouknin, A. Romane, M. Y. Arjouni, and L. Majid, "Mineral composition, multivariate analysis of some oligoelements and heavy metals in some species of genus thymus," Journal of Materials and Environmental Science, vol. 9, pp. 980-985, 2018.

[10] M. J. Mench, A. Manceau, J. Vangronsveld, H. Clijsters, and B. Mocquot, "Capacity of soil amendments in lowering the phytoavailability of sludge-borne zinc," Agronomie, vol. 20, no. 4, pp. 383-397, 2000.

[11] D. Zmirou, P. D. C. Beausoleil, I. Deportes et al., Environnement et Santé Publique Fondements et Pratiques, pp. 397440, University of Montreal, Montreal, Canada, 2003.

[12] S. Belabed, B. Lotmani, and A. Romane, "Assessment of metal pollution in soil and in vegetation near the wild garbage dumps at Mostaganem region," Journal of Materials and Environmental Science, vol. 5, pp. 1551-1556, 2014.

[13] A. Stanojkovic-sebic, R. Pivic, D. Josic, Z. Dinic, and A. Stanojković, "Heavy metals content in selected medicinal plants commonly used as components for herbal formulations," Tarim Bilimleri Dergisi, vol. 21, pp. 317-325, 2014.

[14] K. A. Steindor, I. J. Franiel, W. M. Bierza, B. Pawlak, and B. F. Palowski, "Assessment of heavy metal pollution in surface soils and plant material in the post-industrial city of Katowice, Poland," Journal of Environmental Science and Health, Part A, vol. 51, no. 5, pp. 371-379, 2016. 
[15] H. A. E. Shaaban, A. H. El-Ghorab, and T. Shibamoto, "Bioactivity of essential oils and their volatile aroma components: review," Journal of Essential Oil Research, vol. 24, no. 2, pp. 203-212, 2012.

[16] A. Ouarhach, J. Costa, and A. Romane, "Chemical profiling of Lavandula maroccana of Morocco," Chemistry of Natural Compounds, vol. 56, no. 2, pp. 348-350, 2020.

[17] A. Sayout, A. Ouarhach, I. Dilagui, N. Soraa, and A. Romane, "Antibacterial activity and chemical composition of essential oil from Lavandula tenuisecta Coss.ex Ball. an endemic species from Morocco," The European Journal of Integrative Medicine, vol. 33, p. 101017, 2019.

[18] A. Sayout, A. Ouarhach, R. Rabie, I. Dilagui, N. Soraa, and A. Romane, "Evaluation of antibacterial activity of Lavandula pedunculata subsp. atlantica (Braun-Blanq.) romo essential oil and selected terpenoids against resistant bacteria strains-structure-activity relationships," Chemistry and Biodiversity, vol. 17, p. 1900496, 2020.

[19] E. P. Rybicki, R. Chikwamba, M. Koch, J. I. Rhodes, and J.-H. Groenewald, "Plant-made therapeutics: an emerging platform in South Africa," Biotechnology Advances, vol. 30, no. 2, pp. 449-459, 2012.

[20] S. Wild, G. Roglic, A. Green, R. Sicree, and H. King, "Global prevalence of diabetes: estimates for the year 2000 and projections for 2030," Diabetes Care, vol. 27, no. 5, pp. 1047-1053, 2004.

[21] A. A. Siddiqui, S. A. Siddiqui, S. Ahmad, S. Siddiqui, I. Ahsan, and K. Sahu, "Diabetes: mechanism, pathophysiology and management-a review," International Journal of Drug Development \& Research, vol. 5, pp. 1-23, 2013.

[22] World Health Organization, Diabetes Fact Sheet No 312, World Health Organization, Geneva, Switzerland, 2011.

[23] P. J. Grant, "Beneficial effects of metformin on haemostasis and vascular function in man," Diabetes \& Metabolism, vol. 29, no. 4, pp. 6S44-6S52, 2003.

[24] C. J. Bailey, "Metformin: effects on micro and macrovascular complications in type 2 diabetes," Cardiovascular Drugs and Therapy, vol. 22, no. 3, pp. 215-224, 2008.

[25] H. Pareek, S. Sharma, B. S. Khajja, K. Jain, and G. Jain, "Evaluation of hypoglycemic and anti-hyperglycemic potential of Tridax procumbens (Linn.)," BMC Complementary and Alternative Medicine, vol. 9, no. 1, p. 48, 2009.

[26] M. June, C. N. Kimani, J. M. Mbaria, M. Suleiman, D. Gakuya, and S. G. Kiama, "Antihyperglycemic activity of Zanthoxylum chalybeum stem bark extract in diabetic rats," The Journal of Phytopharmacology, vol. 4, pp. 183-189, 2015.

[27] H. Jouad, M. Haloui, H. Rhiouani, J. El Hilaly, and M. Eddouks, "Ethnobotanical survey of medicinal plants used for the treatment of diabetes, cardiac and renal diseases in the North centre region of Morocco (Fez-Boulemane)," Journal of Ethnopharmacology, vol. 77, no. 2-3, pp. 175-182, 2001.

[28] A. Arya, M. A. Abdullah, B. S. Haerian, and M. A. Mohd, "Screening for hypoglycemic activity on the leaf extracts of nine medicinal plants: in-vivo evaluation," E-Journal of Chemistry, vol. 9, no. 3, pp. 1196-1205, 2012.

[29] World Health Organization, WHO, Geneva, Switzerland, vol. 844, 1994.

[30] A. Lemhadri, "Anti-hyperglycaemic activity of the aqueous extract of Origanum vulgare growing wild in Tafilalet region," Journal of Ethnopharmacology, vol. 92, no. 2-3, pp. 251-256, 2004.

[31] N. A. Mohamed and O. A. Nassier, "The antihyperglycaemic effect of the aqueous extract of Origanium Vulgare leaves in streptozotocin-induced diabetic rats," Jordan Journal of Biological Sciences, vol. 6, no. 1, pp. 31-38, 2013.

[32] L. Zenasni, Etude de polymorphisme chimique des huiles essentielles de thymus satureioides Coss et d'Origanum compactum benth et du genre nepeta et évaluation de leur propriété antibactérienne, Ph.D. Thesis, Mohammed V University, Rabat, Morocco, 2014.

[33] C. Schwartz, "Phytoextraction des métaux des sols pollués par la plante hyperaccumulatrice Thalaspi caerulescens," $\mathrm{Ph}$. D. Thesis, National Polytechnic Institute of Lorraine, Nancy, France, 1997

[34] S. A. Khan, L. Khan, I. Hussain, K. B. Marwat, and N. Akhtar, "Profile of heavy metals in selected medicinal plants," Journal of Weed Sciences and Research, vol. 14, pp. 101-110, 2008.

[35] M. Fadil, A. Farah, B. Ihssane, T. Haloui, and S. Rachiq, "Optimisation des paramètres influençant l'hydrodistillation de Rosmarinus officinalis L. par la méthodologie de surface de réponse optimization of parameters influencing the hydrodistillation of Rosmarinus officinalis $\mathrm{L}$. by response surface methodology," Journal of Materials and Environmental Science, vol. 6, pp. 2346-2357, 2015.

[36] M. Ouknin, A. Romane, J. Costa, and L. Majidi, "Comparative study of the chemical profiling, antioxidant and antimicrobial activities of essential oils of different parts of Thymus willdenowii Boiss \& Reut," Natural Product Research, vol. 33, no. 16 , pp. 2398-2401, 2018.

[37] N. Savithramma, M. Linga Rao, and D. Suhrulatha, "Screening of medicinal plants for secondary metabolites," Middle East Journal of Scientific Research, vol. 8, pp. 579-584, 2011.

[38] S. M’sou, M. Alifriqui, and A. Romane, "Phytochemical study and biological effects of the essential oil of Fraxinus dimorpha Coss \& Durieu," Natural Product Research, vol. 31, no. 23, pp. 2797-2800, 2017.

[39] R. S. Abdul-jabbar, "Polyphenol and flavonoid contents and antioxidant activity in freshly consumed rocket (Eruca sativa)," IOP Conference Series Materials Science and Engineering, vol. 454, p. 012158, 2018.

[40] A. Romane and M. Trimeche, "Total phenolic content, antioxidant and anticorrosive activities of Olea europaea L. and Eucalyptus globulus cultivated in Tunisian arid zones on steel rebar's in alkaline chloride solution," International Journal of Electrochemical Science, vol. 14, p. 7530, 2019.

[41] A. Arvouet-Grand, B. Vennat, A. Pourrat, and P. Legret, "Standardization of propolis extract and identification of principal constituents," Journal de Pharmacie de Belgique, vol. 49, pp. 462-468, 1994.

[42] S. Chakravarty and J. C. Kalita, "Antihyperglycaemic effect of flower of Phlogacanthus Thyrsiflorus Nees on streptozotocin induced diabetic mice," Asian Pacific Journal of Tropical Biomedicine, vol. 2, no. 3, pp. S1357-S1361, 2012.

[43] H. Ouassou, T. Zahidi, S. Bouknana et al., "Inhibition of $\alpha$-glucosidase, intestinal glucose absorption, and antidiabetic properties by Caralluma europaea," Evidence-Based Complementary and Alternative Medicine, vol. 2018, Article ID 9589472, 8 pages, 2018.

[44] K. T. Kee, M. Koh, L. X. Oong, and K. Ng, "Screening culinary herbs for antioxidant and $\alpha$-glucosidase inhibitory activities," International Journal of Food Science \& Technology, vol. 48, no. 9, pp. 1884-1891, 2013.

[45] I. Marmouzi, E. M. Karym, N. Saidi et al., "In vitro and in vivo antioxidant and antihyperglycemic activities of Moroccan oat cultivars," Antioxidants, vol. 6, no. 4, p. 102, 2017. 
[46] A. Bouyahya, J. Abrini, Y. Bakri, and N. Dakka, "Screening phytochimique et évaluation de l'activité antioxydante et antibactérienne des extraits d'Origanum compactum," Phytothérapie, vol. 15, no. 6, pp. 379-383, 2017.

[47] R. Gutierrez, "Effect of Mexican oregano (Lippia graveolens kunth) on streptozotocin induced diabetic mice and its role in regulating carbohydrate metabolic enzymes and their inhibitory effect on the formation of advanced glycation end products," Annual Research \& Review in Biology, vol. 4, no. 23, pp. 3470-3491, 2014.

[48] S. Dhanabal, R. Vadivelan, V. Maithili, and S. Mahendran, "Antidiabetic activity of ethanolic extract of tubers of Dioscorea alata in alloxan induced diabetic rats," Indian Journal of Pharmacology, vol. 43, no. 4, pp. 455-459, 2011.

[49] H. Oualili, H. Rchid, and R. Nmila, "Phytochemical screening and antioxidant activity of: Origanum elongatum and Cupressus atlantica two endemic plants of Morocco," International Journal of Pharmacognosy and Phytochemical Research, vol. 10, pp. 196-200, 2018.

[50] D. Patel, S. Prasad, R. Kumar, and S. Hemalatha, "An overview on antidiabetic medicinal plants having insulin mimetic property," Asian Pacific Journal of Tropical Biomedicine, vol. 2, no. 4, pp. 320-330, 2012.

[51] V. Sornalakshmi, P. Tresina Soris, K. Paulpriya, M. Packia Lincy, and V. R. Mohan, "Oral Glucose Tolerance Test (OGTT) in normal control and glucose induced hyperglycemic rats with Hedyotis leschenaultiana DC," International Journal of Pharmacology and Toxicology, vol. 8, pp. 59-62, 2016.

[52] W. Kooti, M. Farokhipour, Z. Asadzadeh, D. Ashtary-Larky, and M. Asadi-Samani, "The role of medicinal plants in the treatment of diabetes: a systematic review," Electronic physician, vol. 8, no. 1, pp. 1832-1842, 2016.

[53] H. Bischoff, "Pharmacology of $\alpha$-glucosidase inhibition," European Journal of Clinical Investigation, vol. 24, pp. 3-10, 1994.

[54] M. Bnouham, "Medicinal plants with potential antidiabetic activity-a review of ten years of herbal medicine research (1990-2000)," International Journal of Diabetes and Metabolism, vol. 14, pp. 1-25, 2006.

[55] H. E. Lebovitz, "Alpha-glucosidase inhibitors," Endocrinology and Metabolism Clinics of North America, vol. 26, no. 3, pp. 539-551, 1997.

[56] A. B. Evert, J. L. Boucher, M. Cypress et al., "Nutrition therapy recommendations for the management of adults with diabetes," Diabetes Care, vol. 37, no. 1, pp. S120-S143, 2014.

[57] H. N. Gök, D. D. Orhan, I. E. Orhan, N. Orhan, and M. Aslan, "Evaluation of enzyme inhibitory and antioxidant activity of some Lamiaceae plants," Journal of Research in Pharmacy, vol. 23, pp. 749-758, 2019.

[58] M. M. Soliman, M. A. Nassan, and T. A. Ismail, “Origanum majoranum extract modulates gene expression, hepatic and renal changes in a rat model of type 2 diabetes," Iranian Journal of Pharmaceutical Research, vol. 15, pp. 45-54, 2016.

[59] M. Maghrani, A. Lemhadri, H. Jouad, J.-B. Michel, and M. Eddouks, "Effect of the desert plant Retama raetam on glycaemia in normal and streptozotocin-induced diabetic rats," Journal of Ethnopharmacology, vol. 87, no. 1, pp. 21-25, 2003.

[60] V. R. Young, “Trace element biology: the knowledge base and its application for the nutrition of individuals and populations," The Journal of Nutrition, vol. 133, no. 5, pp. 1581S-1587S, 2003.
[61] S. Praveeena, S. Pasula, and K. Sameera, "Trace elements in diabetes mellitus," Journal of Clinical and Diagnostic Research: JCDR, vol. 7, no. 9, pp. 1863-1865, 2013.

[62] H. Derakhshanian, M. H. Javanbakht, M. Zarei, E. Djalali, and M. Djalali, "Vitamin D increases IGF-I and insulin levels in experimental diabetic rats," Growth Hormone \& IGF Research, vol. 36, pp. 57-59, 2017.

[63] P. Dubey, V. Thakur, and M. Chattopadhyay, "Role of minerals and trace elements in diabetes and insulin resistance," Nutrients, vol. 12, no. 6, p. 1864, 2020.

[64] N. Wiernsperger and J. Rapin, "Trace elements in glucometabolic disorders: an update," Diabetology \& Metabolic Syndrome, vol. 2, no. 1, p. 70, 2010.

[65] N. Sanjeevi, J. Freeland-Graves, S. N. Beretvas, and P. K. Sachdev, "Trace element status in type 2 diabetes: a meta-analysis," Journal of Clinical and Diagnostic Research, vol. 12, pp. OE01-OE08, 2018.

[66] P. Rajalakshmy, "Role of micronutrients on type II diabetes mellitus," Acta Scientific Nutritional Health, vol. 3, pp. 44-47, 2019.

[67] A. Gholam hoseinian, B. Shahouzehi, and G. Mohammadi, "Trace elements content of some traditional plants used for the treatment of diabetes mellitus," Biointerface Research in Applied Chemistry, vol. 10, no. 5, pp. 6167-6173, 2020.

[68] A. M. Ahmed, O. F. Khabour, A. H. Awadalla, and H. A. Waggiallah, "Serum trace elements in insulin-dependent and non-insulin-dependent diabetes: a comparative study," Diabetes, Metabolic Syndrome and Obesity: Targets and Therapy, vol. 11, pp. 887-892, 2018.

[69] C. H. Sales, L. F. C. Pedrosa, J. G. Lima, T. M. A. M. Lemos, and C. Colli, "Influence of magnesium status and magnesium intake on the blood glucose control in patients with type 2 diabetes," Clinical Nutrition, vol. 30, no. 3, pp. 359-364, 2011.

[70] D. H. Bonfanti, L. P. Alcazar, P. A. Arakaki et al., "ATPdependent potassium channels and type 2 diabetes mellitus," Clinical Biochemistry, vol. 48, no. 7-8, pp. 476-482, 2015.

[71] P. N. B. Lima, G. B. D. Carvalho, R. K. F. Santos et al., "Intakes of zinc, potassium, calcium, and magnesium of individuals with type 2 diabetes mellitus and the relationship with glycemic control," Nutrients, vol. 10, no. 12, p. 1948, 2018.

[72] C. Ekmekcioglu, I. Elmadfa, A. L. Meyer, and T. Moeslinger, "The role of dietary potassium in hypertension and diabetes," Journal of Physiology and Biochemistry, vol. 72, no. 1, pp. 93-106, 2016.

[73] M. Stone, L. Martyn, and C. Weaver, "Potassium intake, bioavailability, hypertension, and glucose control," Nutrients, vol. 8, no. 7, p. 444, 2016.

[74] J. H. Helderman, D. Elahi, D. K. Andersen et al., "Prevention of the glucose intolerance of thiazide diuretics by maintenance of body potassium," Diabetes, vol. 32, no. 2, pp. 106-111, 1983.

[75] G. Sun, S. Vasdev, G. R. Martin, V. Gadag, and H. Zhang, "Altered calcium homeostasis is correlated with abnormalities of fasting serum glucose, insulin resistance, and -cell function in the newfoundland population," Diabetes, vol. 54, no. 11, pp. 3336-3339, 2005. 